\title{
Anticorrosion of $\mathrm{WO}_{3}$-Modified $\mathrm{TiO}_{2}$ Thin Film Prepared by Peroxo Sol-Gel Method
}

\author{
Jia-Ying Wu, Yu-Wen Chen* \\ Department of Chemical and Materials Engineering, National Central University, Taiwan \\ Email: *ywchen@cc.ncu.edu.tw
}

How to cite this paper: $\mathrm{Wu}, \mathrm{J} . \mathrm{-Y}$. and Chen, Y.-W. (2020) Anticorrosion of $\mathrm{WO}_{3}$ Modified $\mathrm{TiO}_{2}$ Thin Film Prepared by Peroxo Sol-Gel Method. Modern Research in Catalysis, 9, 35-46.

https://doi.org/10.4236/mrc.2020.93003

Received: July 10, 2020

Accepted: July 28, 2020

Published: July 31, 2020

Copyright $\odot 2020$ by author(s) and Scientific Research Publishing Inc. This work is licensed under the Creative Commons Attribution International License (CC BY 4.0).

http://creativecommons.org/licenses/by/4.0/

\section{(c) (i) Open Access}

\begin{abstract}
The aim of this study was to develop a method to prepare $\mathrm{WO}_{3}-\mathrm{TiO}_{2}$ film which has high anticorrosion property when it was coated on type 304 stainless steel. A series of $\mathrm{WO}_{3}$-modified $\mathrm{TiO}_{2}$ sols were synthesized by peroxo-sol gel method using $\mathrm{TiCl}_{4}$ and $\mathrm{Na}_{2} \mathrm{WO}_{4}$ as the starting materials. $\mathrm{TiCl}_{4}$ was converted to $\mathrm{Ti}(\mathrm{OH})_{4}$ gel. $\mathrm{H}_{2} \mathrm{O}_{2}$ and $\mathrm{Na}_{2} \mathrm{WO}_{4}$ were added in $\mathrm{Ti}(\mathrm{OH})_{4}$ solution and heated at $95^{\circ} \mathrm{C}$. The $\mathrm{WO}_{3}-\mathrm{TiO}_{2}$ sol was transparent, in neutral ( $\left.\mathrm{pH} \sim 7\right)$ solution, stable suspension without surfactant, nano-crystallite and no annealing is needed after coating, and very stable for 2 years in stock. $\mathrm{WO}_{3}-\mathrm{TiO}_{2}$ sol was formed with anatase crystalline structure. These sols were characterized by XRD, TEM, and XPS. The sol was used to coat on stainless steel 304 by dip-coating. The $\mathrm{WO}_{3}-\mathrm{TiO}_{2}$ was anatase in structure as characterized by $\mathrm{X}$-ray diffraction. There were no $\mathrm{WO}_{3} \mathrm{XRD}$ peaks in the $\mathrm{WO}_{3}-\mathrm{TiO}_{2}$ sols, indicating that $\mathrm{WO}_{3}$ particles were very small, possibly incorporating into $\mathrm{TiO}_{2}$ structure, providing the amount of $\mathrm{WO}_{3}$ was very small. The $\mathrm{TiO}_{2}$ particles were rhombus shape. $\mathrm{WO}_{3}-\mathrm{TiO}_{2}$ had smaller size area than pure $\mathrm{TiO}_{2}$. The SEM results showed that the film coated on the glass substrate was very uniform. All films were nonporous and dense films. Its hardness reached $2 \mathrm{H}$ after drying at $100^{\circ} \mathrm{C}$, and reached $5 \mathrm{H}$ after annealing at $400^{\circ} \mathrm{C}$. The $\mathrm{WO}_{3}-\mathrm{TiO}_{2}$ film coated on 304 stainless steel had better anticorrosion capability than the unmodified $\mathrm{TiO}_{2}$ film under UV light illumination. The optimum weight ratio of $\mathrm{TiO}_{2}: \mathrm{WO}_{3}$ was 100:4.
\end{abstract}

\section{Keywords}

Anticorrosion, Photocatalyst, Nanocoating, $\mathrm{WO}_{3}-\mathrm{TiO}_{2}$, Coating, Sol-Gel Method, Nanomaterial

\section{Introduction}

$\mathrm{TiO}_{2}$ has been well-known to be the good material for anticorrosion [1]. Yuan 
and Tsujikawa [2] coated $\mathrm{TiO}_{2}$ onto type 304 stainless steel, and reported that $\mathrm{TiO}_{2}$ could protect the inner substrate stainless steel. The similar effects were reported by Tatsuma et al. [3] under UV light and $\gamma$-ray irradiation. They reported a photoelectrochemical anticorrosion system about $\mathrm{TiO}_{2}-\mathrm{WO}_{3}$. This research revealed an energy storage system with a sufficient capacity, which using $\mathrm{WO}_{3}$ as an electron storage pool to receive the photogenerated electrons from $\mathrm{TiO}_{2}$ conduction band. This system can promise that it can be effective in the dark for a while [3]. Adding $\mathrm{WO}_{3}$ into $\mathrm{TiO}_{2}$ can promote the anticorrosion capability under visible light irradiation [4]-[15]. However, most of previous studies used powder form or sol in acidic solution [4] [14] [15] [16] [17]. The powder $\mathrm{WO}_{3}-\mathrm{TiO}_{2}$ cannot be used to coat on substrate. The acidic sol is difficult to handle and cannot coat on some substrates. In previous studies, one of the authors has developed a peroxo-sol gel method to prepare $\mathrm{TiO}_{2}$ sol. It is very stable and transparent after coating on substrate. None of previous literature was reported on $\mathrm{WO}_{3}-\mathrm{TiO}_{2}$ sol prepared by peroxo-sol gel method.

The aim of this study was to develop a method to prepare $\mathrm{WO}_{3}-\mathrm{TiO}_{2}$ sol by peroxo sol-gel method. The $\mathrm{WO}_{3}-\mathrm{TiO}_{2}$ sol was 1) transparent, 2) in neutral (pH 7) solution, 3) stable suspension without surfactant, 4) nano-crystallite and no annealing is needed after coating, 5) very stable for 2 years in stock. We also tried to find the optimum doping amount of $\mathrm{WO}_{3}$, and to investigate its effect on anticorrosion after coating on stainless steel type 304.

\section{Experimental}

\subsection{Preparation of $\mathrm{WO}_{3}-$ Modified $\mathrm{TiO}_{2}$ Sols}

$\mathrm{Na}_{2} \mathrm{WO}_{4}$ was purchased from Aldrich. The detail procedure of preparing $\mathrm{WO}_{3}$-modified $\mathrm{TiO}_{2}$ sol is as follows. The preparation method was the same as synthesis of pure $\mathrm{TiO}_{2}$ sol, as reported in the previous studies [18]. The only difference was that $\mathrm{Na}_{2} \mathrm{WO}_{4}$ and $\mathrm{H}_{2} \mathrm{O}_{2}$ were added in the heating step at $95^{\circ} \mathrm{C}$ for 6 $\mathrm{h}$ under magnetic stirring. $6 \mathrm{~h}$ later, the transparent light yellow $\mathrm{WO}_{3}-\mathrm{TiO}_{2}$ sol was obtained. The molar ratio of $\mathrm{TiO}_{2}: \mathrm{H}_{2} \mathrm{O}_{2}$ was 1: 6 and the weight ratio of $\mathrm{WO}_{3}: \mathrm{TiO}_{2}$ was $0.5: 100,1: 100,2: 100$ and $4: 100$, respectively. $\mathrm{Ti}(\mathrm{OH})_{4}$ and $\mathrm{Na}_{2} \mathrm{WO}_{4}$ were converted to $\mathrm{WO}_{3}-\mathrm{TiO}_{2}$ crystallites at $95^{\circ} \mathrm{C}$ in the presence of $\mathrm{H}_{2} \mathrm{O}_{2}$. It should be noted that there was no surfactant was added. The sol was very stable even after 2 years in stock.

\subsection{Preparation of $\mathrm{WO}_{3}-\mathrm{TiO}_{2}$ Films}

$\mathrm{WO}_{3}-\mathrm{TiO}_{2}$ films were prepared by dip-coating method using the as-prepared $\mathrm{WO}_{3}-\mathrm{TiO}_{2}$ sols. The substrate was type 304 stainless steel. The total coating surface area of the substrate was $40 \mathrm{~cm}^{2}$. Before coating, the substrate was cleaned by neutral abrasives and distilled water for several times, and then dried in an oven at $50^{\circ} \mathrm{C}$. The substrate was vertically soaked into the as-prepared sol for 2 $\mathrm{min}$, then pull out with the constant speed of $60 \mathrm{~cm} / \mathrm{min}$ for 6 times. The thickness of $\mathrm{WO}_{3}-\mathrm{TiO}_{2}$ films was kept around $120 \mathrm{~nm}$. After coating, it was heated at 
$400^{\circ} \mathrm{C}$. The number in parentheses means the weight percentage of $\mathrm{WO}_{3}$ in the sample (Figure 1).

\subsection{Characterization}

\subsubsection{X-Ray Diffraction (XRD)}

The sample was prepared by drying the $\mathrm{WO}_{3}-\mathrm{TiO}_{2}$ sol at $100^{\circ} \mathrm{C}$ for 2 days to obtain the powder form. The sample was calcined at $400^{\circ} \mathrm{C}$ for $2 \mathrm{~h}$. The crystalline structure of the as-prepared $\mathrm{WO}_{3}$-modified $\mathrm{TiO}_{2}$ powder was performed using Simens D500 powder diffractometer using $\mathrm{CuK}_{\alpha}$ radiation $(\lambda=1.5405 \AA)$ at a voltage and current of $40 \mathrm{kV}$ and $40 \mathrm{~mA}$, respectively.

\subsubsection{Scanning Electron Microscopy (SEM)}

The morphology and thickness of films were observed by Hitachi-3000 with tungsten lamp at acceleration voltage of $10 \mathrm{kV}$ and emission current of 81,000 $\mathrm{nA}$. The SEM sample was prepared by cutting the coated glass substrate into 0.5 $\mathrm{cm} \times 0.5 \mathrm{~cm}$ piece with a diamond knife first and then coated with platinum to increase its conductivity.

\subsubsection{Transmission Electron Microscopy (TEM)}

The morphology and structure of $\mathrm{WO}_{3}-\mathrm{TiO}_{2}$ sol were observed by TEM (JEM-2000 EX II) operated at $160 \mathrm{kV}$ or $200 \mathrm{kV}$. The TEM sample was prepared by dipping the carbon-coated copper grid (200 meshes) (Ted Pella) into as-prepared sol for 3 times.

\subsection{Anticorrosion Test}

The following methods were used to investigate the effect of $\mathrm{WO}_{3}-\mathrm{TiO}_{2}$ coating on anticorrosion capability of stainless steel 304 .

\subsubsection{The State of Corrosion}

One of the methods to examine the state of the metal substrate is to place the coated substrate in a $3-5 \mathrm{wt} \%$ aqueous sodium chloride $(\mathrm{NaCl})$ solution to carry

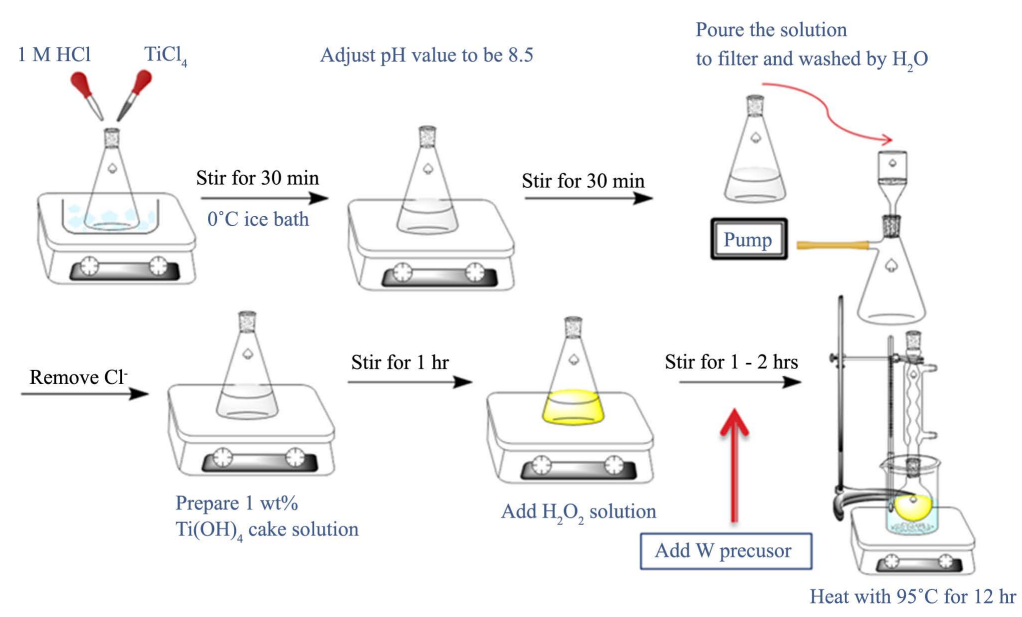

Figure 1. The procedure of preparing $\mathrm{WO}_{3}-\mathrm{TiO}_{2}$ sol. 
out the salt spray test which is based on ASTM B- 17 . To speed the test, $5 \mathrm{wt} \%$ sulfuric acid aqueous solutions was used in this study. The state of the coated substrates was examined every $2 \mathrm{~h}$. The weight of the substrates was measured every test and the corrosion degree $\left(\mathrm{mg} / \mathrm{dm}^{2} \cdot\right.$ day) and erodibility $(\mathrm{mm} /$ year) were calculated.

$$
\begin{gathered}
\text { Corrosion degree }\left(\mathrm{mg} / \mathrm{dm}^{2} \cdot \text { day }\right)=\frac{\Delta W}{S \times H} \times 24 \times 10^{5} \\
\text { Erodibility }(\mathrm{mm} / \text { year })=\frac{W_{1}-W_{2}}{d \times S} \times \frac{365 \times 24}{H} \times 10=\frac{\Delta W}{d \times S \times H} \times 87600
\end{gathered}
$$

where $W_{1}$ is the weight before soaking into acidic solution (before testing) (g), $W_{2}$ is the weight after soaking into acidic solution (after rusting) (g), $\Delta W$ is the difference between $W_{1}$ and $W_{2}(\mathrm{~g}), d$ is density $\left(\mathrm{g} / \mathrm{cm}^{3}\right), S$ is surface area $\left(\mathrm{cm}^{2}\right)$, and $H$ is testing time (h).

\subsubsection{Four-Point Probe}

Four-point probe is the most commonly used instrument to measure the sheet resistance. As long as adding constant current into two probes, simultaneously measuring the voltage difference between the two probes, and the sheet resistance can be calculated.

The resistivity and sheet resistance were calculated by the following equation:

$$
R=\frac{\rho}{t} \frac{l}{w}=R_{s} \frac{l}{w}
$$

where $R$ is resistance values $(\Omega), \rho$ is resistivity $(\Omega-\mathrm{cm}), l$ is the length of specimen $(\mathrm{cm}), w$ is the width of specimen $(\mathrm{cm}), t$ is the thickness of specimen $(\mathrm{cm})$, and $R_{s}$ is sheet resistance ( $\Omega$ /unit area).

\subsubsection{Cyclic Voltammeter}

The cyclic voltammeter is an instrument that can control the potential, and it can detect the current of electrochemical reaction. In the beginning, the electrode was washed by ultrapure water. The electrode was put in a beaker which contained $5 \mathrm{wt} \% \mathrm{NaCl}$ solution. The OCP (Open Circuit Potential) was tested firstly and then the scanning potential range was set from $-0.8 \mathrm{~V}$ to $0.6 \mathrm{~V}$. The scanning rate of set potential was $0.05 \mathrm{~V} / \mathrm{s}$, and the scanning circles were 9 . The method to analyze the effect of anticorrosion is electric polarization curve. The upper curve is anodic polarization and the lower one is the cathodic polarization curve. The anodic polarization curve represents the reduction of hydrogen during the whole experiment, i.e., $2 \mathrm{H}^{+}+2 \mathrm{e}^{-} \rightarrow \mathrm{H}_{2}$. The cathodic polarization curve shows the oxidation of metal, i.e., $\mathrm{M} \rightarrow \mathrm{Mn}^{+}+\mathrm{ne}^{-}$. Ecorr represents the potential that working electrode starts corrosion. The $\mathrm{I}_{\text {corr }}$ represents the corrosion current, which is the corrosion rate.

\section{Results and Discussion}

\subsection{Characteristics of $\mathrm{WO}_{3}-\mathrm{TiO}_{2}$ Sols}

$\mathrm{WO}_{3}-\mathrm{TiO}_{2}$ sol was light yellow transparent sol containing $\mathrm{WO}_{3}-\mathrm{TiO}_{2}$ nanoparticles dispersed in water. The yellow color was due to the presence of small 
amount of titanium peroxide [18]. If one decreased the amount of $\mathrm{H}_{2} \mathrm{O}_{2}$ in preparation, the color became light yellow. The $\mathrm{pH}$ values of $\mathrm{TiO}_{2}$ and $\mathrm{WO}_{3}-\mathrm{TiO}_{2}$ sols are listed in Table 1. The $\mathrm{pH}$ value of $\mathrm{TiO}_{2}$ sol was 8.7. Adding $\mathrm{WO}_{3}$ in $\mathrm{TiO}_{2}$ sol decreased the $\mathrm{pH}$ value very slightly because the tungsten precursor was acidic and its amount was very low.

\subsection{XRD}

The XRD patterns of all the samples are shown in Figure 3. The result in Figure 3 represents the anatase $\mathrm{TiO}_{2}$ diffraction peaks located at $2 \theta=25.4102^{\circ}$, $37.9658^{\circ}, 48.1227^{\circ}, 62.7199^{\circ}$, and $75.2245^{\circ}$ corresponding to the anatase phase of (101), (004), (200), (204), and (215). The as-prepared $\mathrm{TiO}_{2}$ had low intensity peaks for anatase, as shown in Figure 2(b), because the $\mathrm{TiO}_{2}$ crystallites were very small, in agreement with literature data [14] [15] [16] [17] [18]. Figure 3 shows the XRD patterns of $\mathrm{WO}_{3}-\mathrm{TiO}_{2}$ samples. The diffraction peaks of these patterns coincide with the characteristic peaks of anatase $\mathrm{TiO}_{2}$ and did not match any diffraction peak of $\mathrm{WO}_{3}$. This is because the amount of $\mathrm{WO}_{3}$ in $\mathrm{WO}_{3}-\mathrm{TiO}_{2}$ sample was very small. The characteristic peaks of $\mathrm{WO}_{3} \cdot \mathrm{H}_{2} \mathrm{O}$ are at $2 \theta=25.7164^{\circ}, 35.1076^{\circ}$, and $52.7672^{\circ}$. In order to check whether the diffraction peaks of $\mathrm{WO}_{3}$ appeared in $\mathrm{W}-\mathrm{TiO}_{2}$ samples or not, we added more amount of $\mathrm{W}$ precursors in the sample. Figure 5 shows the XRD pattern of $1 \mathrm{wt} \%$ $\mathrm{WO}_{3}$-modified $\mathrm{TiO}_{2}$ using $\mathrm{H}_{2} \mathrm{WO}_{4}$ as the precursor. There were no $\mathrm{WO}_{3} \mathrm{XRD}$ peaks in Figure 5. Tatsuma et al. [3] reported that $\mathrm{WO}_{3}$ was highly dispersed in the bulk phase of $\mathrm{TiO}_{2}$ particles and a new solid such as $\mathrm{WO}_{3}$ was not formed. Our results are in accord.

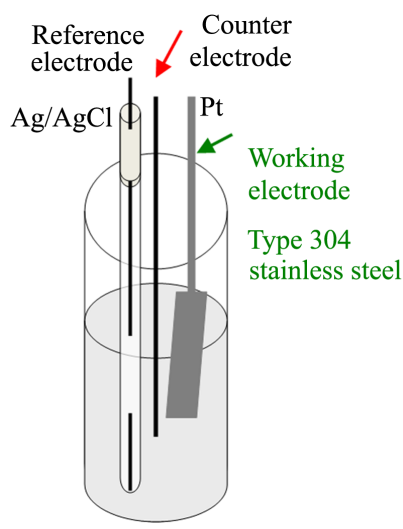

Figure 2. The schematic diagram of cyclic voltammeter.

Table 1. The $\mathrm{pH}$ values of the as-prepared sols.

\begin{tabular}{cc}
\hline Sample & $\mathrm{pH}$ value \\
\hline $\mathrm{TiO}_{2}$ & 8.78 \\
$\mathrm{WT}(0.5)$ & 8.78 \\
$\mathrm{WT}(1)$ & 8.68 \\
$\mathrm{WT}(2)$ & 8.43 \\
WT (4) & 8.32 \\
\hline
\end{tabular}




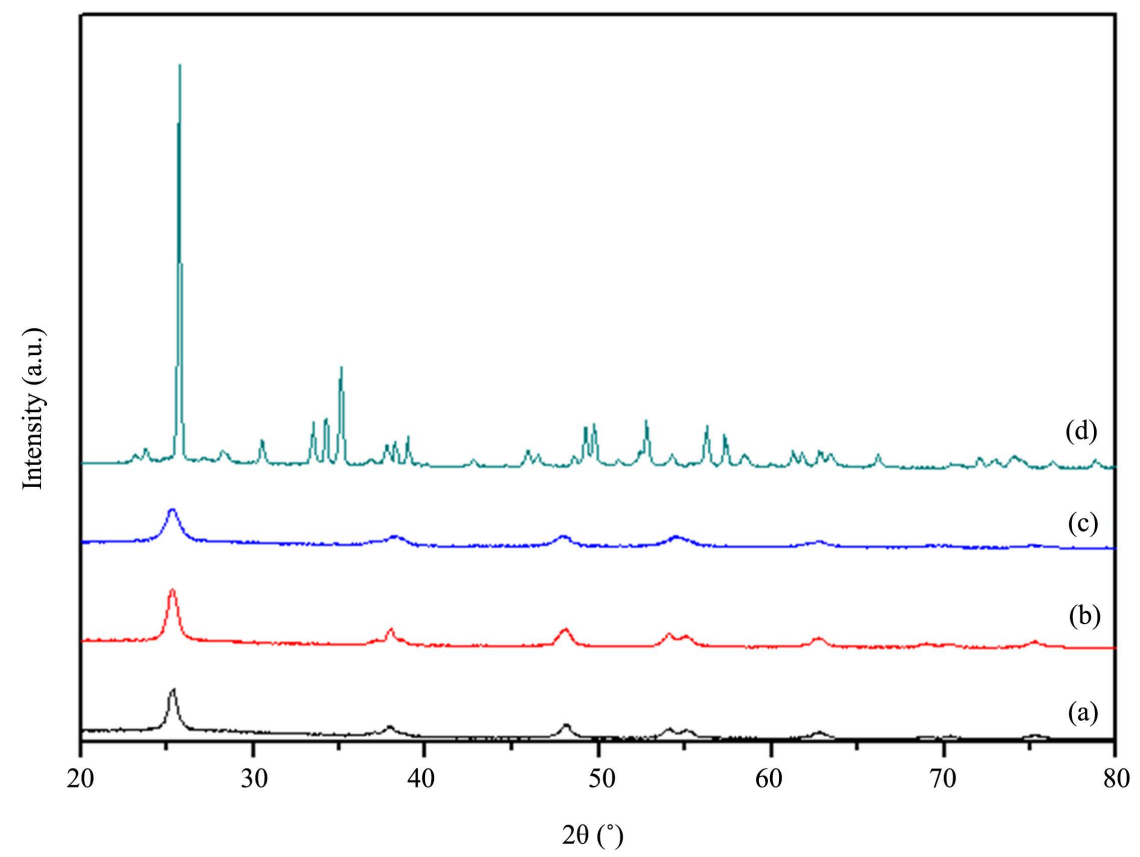

Figure 3. XRD patterns of (a) $\mathrm{TiO}_{2}$; (b) WT (10); (c) WT (100); and (d) $\mathrm{WO}_{3}$.

\subsection{SEM}

The structure of $\mathrm{TiO}_{2}$ and $\mathrm{WO}_{3}-\mathrm{TiO}_{2}$ films were examined by SEM. The top-view surface structure and cross-section view of the as-prepared thin film are shown in Figure 4. Each sample had very uniform and smooth surface of film on the top of substrate, indicating that dip coating is a good way to prepare the thin film. The surface of $\mathrm{TiO}_{2}$ film was smoother than those of $\mathrm{WO}_{3}-\mathrm{TiO}_{2}$ samples. All films were nonporous and dense films. Its hardness reached $2 \mathrm{H}$ after drying at $100^{\circ} \mathrm{C}$, and reached $5 \mathrm{H}$ after annealing at $400^{\circ} \mathrm{C}$.

\subsection{TEM}

The morphology of as-prepared $\mathrm{WO}_{3}-\mathrm{TiO}_{2}$ sols was analyzed by TEM and HRTEM. HRTEM image in Figure 5(a) shows that the $\mathrm{TiO}_{2}$ particles were rhombus shape with the major axis and minor axis of $30-50 \mathrm{~nm}$ and $15-30$ $\mathrm{nm}$, respectively. Figure 5 also shows the morphology and particle size of the as-prepared $\mathrm{WO}_{3}-\mathrm{TiO}_{2}$. Comparing with pure $\mathrm{TiO}_{2}$ sol, the particle sizes of $\mathrm{WO}_{3}-\mathrm{TiO}_{2}$ was smaller than that of $\mathrm{TiO}_{2}$. It is in agreement with the literature

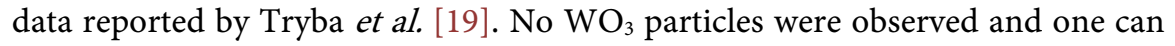
conclude that $\mathrm{W}$ atoms were incorporated into the structure of $\mathrm{TiO}_{2}$, providing that the concentration of $\mathrm{W}$ precursor was low. In conclusion, we have successfully developed a method to prepare $\mathrm{WO}_{3}-\mathrm{TiO}_{2}$ sample.

\subsection{Anticorrosion Test}

The samples were loaded in the $5 \mathrm{wt} \%$ sulfuric acid solution to test their anticorrosion capabilities. The results are shown in Table 2 and Table 3. Table 2 shows the results tested for $24 \mathrm{~h}$ and Table 3 shows the results tested for $48 \mathrm{~h}$. 


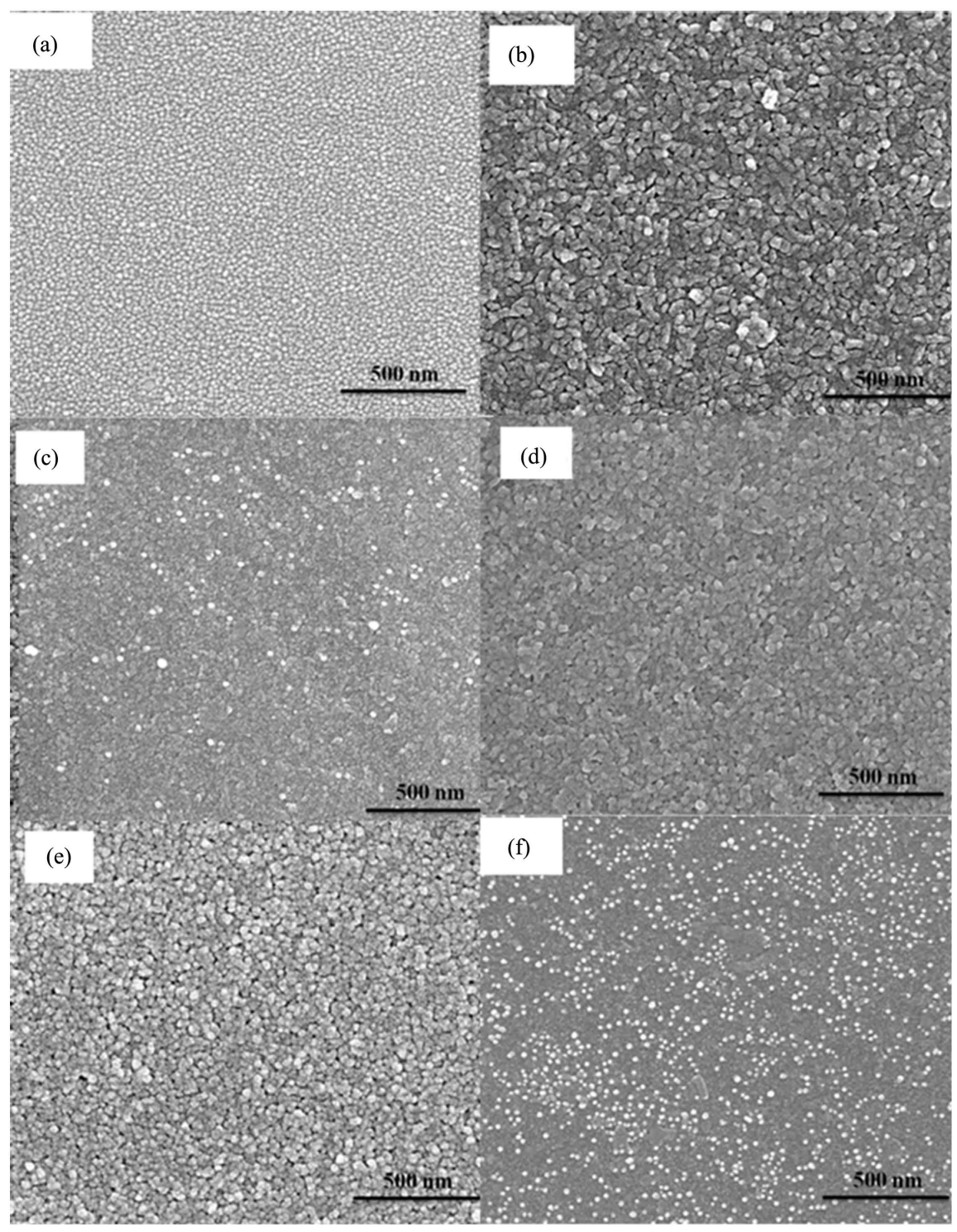

Figure 4. Top-view SEM images of the surface structure of (a) $\mathrm{TiO}_{2}$ film; (b) WT (0.5) film; (c) WT (1) film; (d) WT (2) film; (e) HT (10) film and (f) HT (100) film.

Table 2. Weight loss of various samples in the $5 \mathrm{wt} \%$ sulfuric acid solution after $24 \mathrm{~h}$.

\begin{tabular}{cccc}
\hline Coating & $\begin{array}{c}\text { weight before test } \\
(\mathrm{g})\end{array}$ & $\begin{array}{c}\text { weight after test } \\
(\mathrm{g})\end{array}$ & $\begin{array}{c}\text { Rate of corrosion } \\
\times 10^{5}\left(\mathrm{~g} / \mathrm{cm}^{2} \cdot \mathrm{min}\right)\end{array}$ \\
\hline Bare substrate & 9.0930 & 6.9609 & 12.339 \\
$\mathrm{TiO}_{2}$ & 9.0989 & 7.4859 & 9.334 \\
$\mathrm{WT}(0.5)$ & 9.0942 & 7.5393 & 8.998 \\
$\mathrm{WT}(1)$ & 9.0778 & 7.5759 & 8.692 \\
$\mathrm{WT}(2)$ & 9.0733 & 7.4347 & 9.483 \\
$\mathrm{WT}(4)$ & 9.0635 & 7.4322 & 9.440 \\
$\mathrm{WO}_{3}$ & 9.1027 & 7.3400 & 10.201 \\
\hline
\end{tabular}




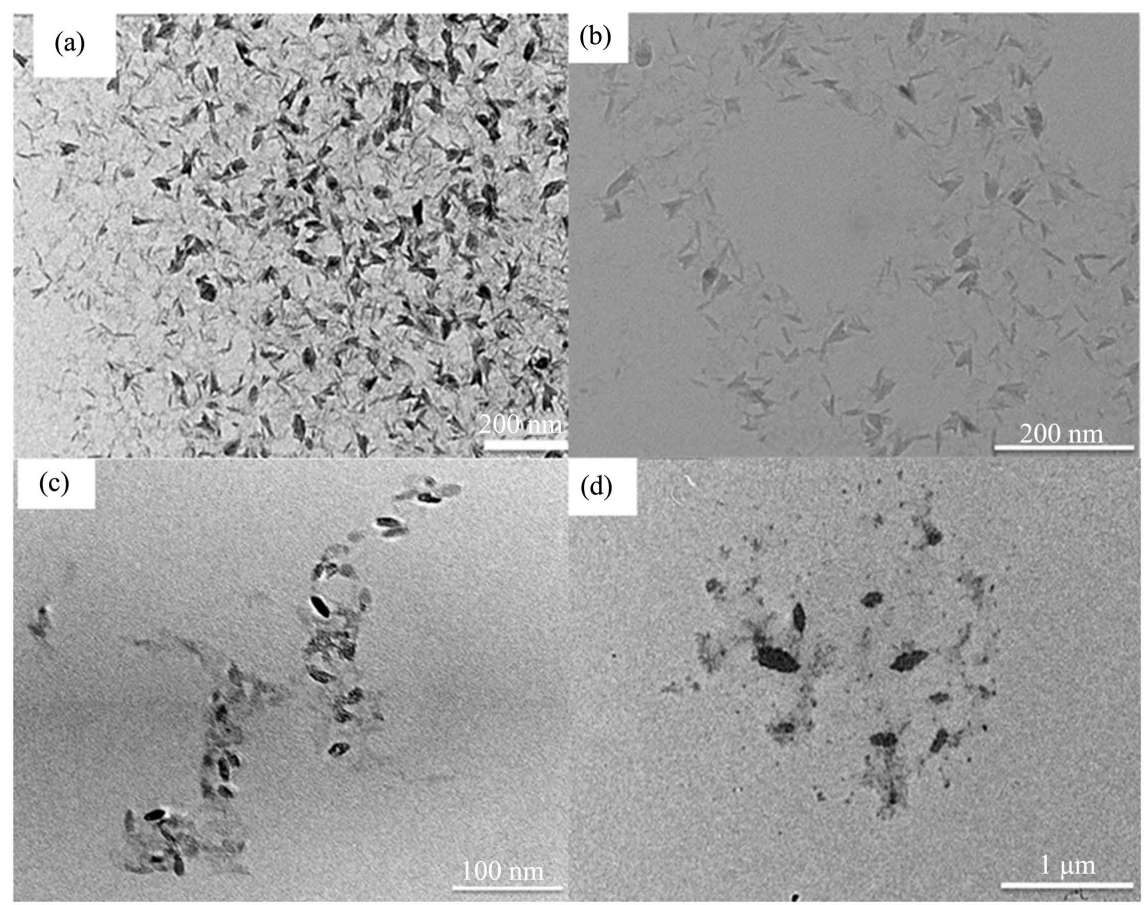

Figure 5. TEM image of (a) $\mathrm{TiO}_{2}$; (b) WT (4) sol; (c) WT (10) sol and (d) $\mathrm{WO}_{3}$ sol.

Table 3. Weight loss of the sample in $5 \mathrm{wt} \%$ sulfuric acid solution after $48 \mathrm{~h}$.

\begin{tabular}{cccc}
\hline Sample & $\begin{array}{c}\text { weight before test } \\
(\mathrm{g})\end{array}$ & $\begin{array}{c}\text { weight after test } \\
(\mathrm{g})\end{array}$ & $\begin{array}{c}\text { rate of corrosion } \\
\times 10^{-5}\left(\mathrm{~g} / \mathrm{cm}^{2} \cdot \mathrm{min}\right)\end{array}$ \\
\hline Bare substrate & 9.0975 & 5.7162 & 19.57 \\
$\mathrm{TiO}_{2}$ & 9.0945 & 6.3181 & 16.07 \\
$\mathrm{WT}(0.5)$ & 9.0990 & 6.2845 & 16.29 \\
$\mathrm{WT}(1)$ & 9.0504 & 6.3375 & 15.70 \\
$\mathrm{WT}(2)$ & 9.0725 & 6.2969 & 16.06 \\
$\mathrm{WT}(4)$ & 9.0458 & 6.3673 & 15.50 \\
$\mathrm{WO}_{3}$ & 9.0741 & 6.2388 & 16.41 \\
\hline
\end{tabular}

The bare sample without coating had very low resistance to corrosion. One can see in Table 2 that sample WT (1) had the lowest weight loss by corrosion, indicating that it had the best anticorrosion performance among all the samples. Instead, $\mathrm{WO}_{3}$ sample had low anticorrosion capability. Table 2 and Table 3 also show that the weight losses of all the samples coated with $\mathrm{WO}_{3}-\mathrm{TiO}_{2}$ films were almost the same. The difference was small because the short time test was used. The results indicated that $\mathrm{TiO}_{2}$ has good anticorrosion property. Adding suitable amount of $\mathrm{WO}_{3}$ in $\mathrm{TiO}_{2}$ improved the anticorrosion property of $\mathrm{TiO}_{2} . \mathrm{WO}_{3}$ can store the electrons generated by $\mathrm{TiO}_{2}$ under light irradiation [6]. It also can improve the separation of electron-hole pairs, resulting in high anticorrosion capability [10] [11] [15].

Anticorrosion property of the sample was examined by four-point probe to 
determine the conductivity of the test specimen. If the conductivity of the specimen is high, the oxidative capacity is high, and its ability of anticorrosion is low. By applying an electric potential $(1 \mathrm{~V})$ and current $(0.4 \mathrm{~A})$ to the sample, the conductivity was zero in each sample, except the bare 304 stainless steel as shown in Table 4, indicating that all samples with coating had high anticorrosion property in the presence of and absence of light illumination.

\subsection{Analysis by Cyclic Voltammeter}

The corrosion resistance and the behavior of materials were evaluated by the potentiostatic and potentiodynamic polarization methods. Figure 6 shows that the I- $\mathrm{V}$ curves of all samples were very smooth in the range between $-0.6 \mathrm{~V}$ and $-0.05 \mathrm{~V}$. It illustrates that no obvious electrochemical reactions occurred in this region. This result has been initially applied to explain that coating onto the substrate would retard the electrochemical reactions.

Figure 6 shows that WT (4) sample had the lowest current density and $\mathrm{TiO}_{2}$ sample had the highest current density. High current density infers low anticorrosion property. Figure 6 shows that the best sample had the weight ratio of $\mathrm{TiO}_{2}: \mathrm{WO}_{3}$ of 100:4. The amounts of charge of all samples are listed in Table 5. The higher the amount of charge means the lower the anticorrosion capability.

The results show that all of the samples had better anticorrosion capability than the unmodified $\mathrm{TiO}_{2}$.

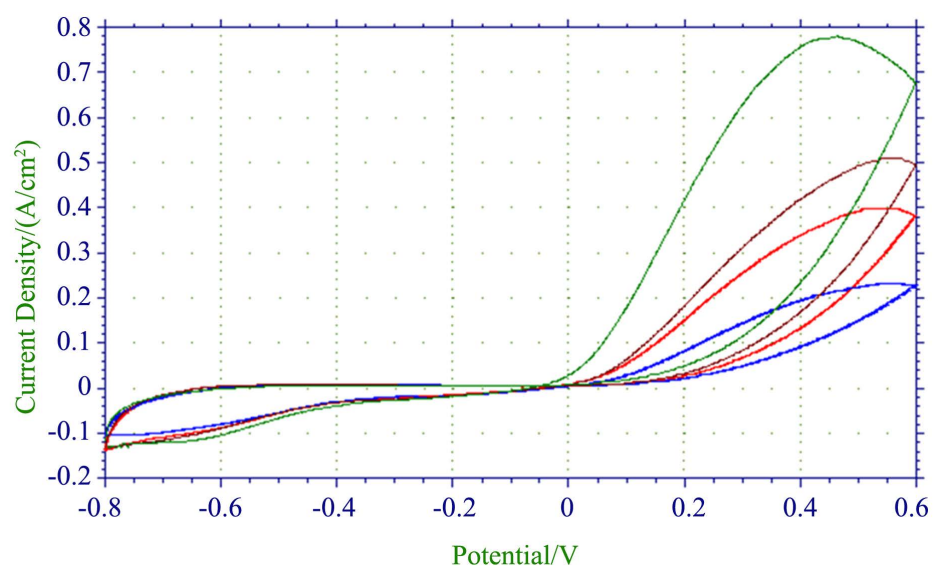

Figure 6. The I-V curve of coated $\mathrm{W}$-modified $\mathrm{TiO}_{2}$ sol onto type 304 stainless steel. From top to bottom are $\mathrm{TiO}_{2}$, WT (1), WT (2), and WT (4).

Table 4. The experimental values of four-point probe for all samples.

\begin{tabular}{ccc}
\hline Sample & With light irradiation & Without light illumination \\
\hline Bare 304 stainless steel & $1.002 \mathrm{~V}, 0.260 \mathrm{~A}$ & $1.002 \mathrm{~V}, 0.260 \mathrm{~A}$ \\
$\mathrm{TiO}_{2}$ & $\mathrm{X}$ & $\mathrm{X}$ \\
$\mathrm{WT}(0.5)$ & $\mathrm{X}$ & $\mathrm{X}$ \\
$\mathrm{WT}(1)$ & $\mathrm{X}$ & $\mathrm{X}$ \\
WT (2) & $\mathrm{X}$ & $\mathrm{X}$ \\
\hline
\end{tabular}

"X" means that the conductivity was zero. 
Table 5. Amount of charge of all samples.

\begin{tabular}{cc}
\hline Sample & $\mathrm{Q}\left(10^{-1} \times \mathrm{C}\right)$ \\
\hline $\mathrm{TiO}_{2}$ & 10.47 \\
$\mathrm{WT}(0.5)$ & 10.08 \\
$\mathrm{WT}(1)$ & 9.85 \\
$\mathrm{WT}(2)$ & 8.19 \\
$\mathrm{WT}(4)$ & 8.13 \\
\hline
\end{tabular}

\section{Conclusions}

A series of $\mathrm{WO}_{3}$-modified $\mathrm{TiO}_{2}$ sols with various $\mathrm{WO}_{3}$ contents were synthesized by peroxo sol-gel method. The as-prepared $\mathrm{WO}_{3}$-modified $\mathrm{TiO}_{2}$ sols were transparent with very light yellow color. The sols were very stable even after 2 years. The sol was used to coat on 304 stainless steel by dip coating for anticorrosion test. Its hardness reached $2 \mathrm{H}$ after drying at $100^{\circ} \mathrm{C}$, and reached $5 \mathrm{H}$ after annealing at $400^{\circ} \mathrm{C}$.

The crystalline phase of $\mathrm{TiO}_{2}$ in sol was anatase. There were no $\mathrm{WO}_{3} \mathrm{XRD}$ peaks in the $\mathrm{WO}_{3}-\mathrm{TiO}_{2}$ sols, indicating that $\mathrm{WO}_{3}$ particles were very small, possibly incorporating into $\mathrm{TiO}_{2}$ structure, providing the amount of $\mathrm{WO}_{3}$ was very small. The $\mathrm{TiO}_{2}$ particles were rhombus shape. $\mathrm{WO}_{3}-\mathrm{TiO}_{2}$ had smaller size area than pure $\mathrm{TiO}_{2}$. The SEM results showed that the film coated onto glass substrate were very uniform. The $\mathrm{WO}_{3}-\mathrm{TiO}_{2}$ coating on 304 stainless steel had better anticorrosion capability than the unmodified $\mathrm{TiO}_{2}$ coating. The optimum weight ratio of $\mathrm{TiO}_{2}: \mathrm{WO}_{3}$ was 100:4.

\section{Acknowledgements}

This research was supported by the Ministry of Science and Technology, Taiwan.

\section{Conflicts of Interest}

The authors declare no conflicts of interest regarding the publication of this paper.

\section{References}

[1] Shan, C.X., Hou, X. and Choy, K.L. (2008) Corrosion Resistance of $\mathrm{TiO}_{2}$ Films Grown on Stainless Steel by Atomic Layer Deposition. Surface and Coatings Technology, 202, 2399-2402. https://doi.org/10.1016/j.surfcoat.2007.08.066

[2] Yuan, J. and Tsujikawa, S. (1995) Characterization of Sol-Gel-Derived $\mathrm{TiO}_{2}$ Coatings and Their Photoeffects on Copper Substrates. Journal of Electrochemical Society, 142, 3444-3455. https://doi.org/10.1149/1.2050002 https://citeseerx.ist.psu.edu/viewdoc/download?doi=10.1.1.846.8347\&rep=rep1\&typ $\underline{\mathrm{e}=\mathrm{pdf}}$

[3] Tatsuma, T., Saitoh, S., Ohko, Y. and Fujishima, A. (2001) $\mathrm{TiO}_{2}-\mathrm{WO}_{3}$ Photoelectrochemical Anticorrosion System with an Energy Storage Ability. Chemistry of Materials, 13, 2838-2842. https://doi.org/10.1021/cm010024k 
[4] Ngaotrakanwiwat, P., Tatsuma, T., Saitoh, S., Ohko, Y. and Fujishima, A. (2003) Charge-Discharge Behavior of $\mathrm{TiO}_{2}-\mathrm{WO}_{3}$ Photocatalysis Systems with Energy Storage Ability. Physical Chemistry and Chemical Physics, 5, 3234-3237.

https://pubs.rsc.org/en/content/articlelanding/2003/cp/b304181f\#!divAbstract https://doi.org/10.1039/B304181F

[5] Kalidindi, N.R., Manciu, F.S. and Ramana, C.V. (2011) Crystal Structure, Phase, and Electrical Conductivity of Nanocrystalline $\mathrm{W}_{0.95} \mathrm{Ti}_{0.05} \mathrm{O}_{3}$ Thin Films. ACS Applied Materials Interfaces, 3, 863-868. https://doi.org/10.1021/am101209d

[6] Yang, Y. and Cheng, Y.F. (2020) Visible Light Illuminated High-Performance

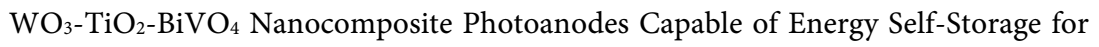
Photo-Induced Cathodic Protection. Corrosion Science, 164, 108333-108340.

https://www.sciencedirect.com/science/article/abs/pii/S0010938X19317160 https://doi.org/10.1016/j.corsci.2019.108333

[7] Zhao, D., Chen, C., Yu, C., Ma, W. and Zhao, J. (2009) Photoinduced Electron Storage in $\mathrm{WO}_{3} / \mathrm{TiO}_{2}$ Nanohybrid Material in the Presence of Oxygen and Postirradiated Reduction of Heavy Metal Ions. Journal Physical Chemistry C, 113, 13160-13165. https://doi.org/10.1021/jp9002774

[8] Couselo, N., Einschlag, F.S.G., Candal, R.J. and Jobbágy, M. (2008) Tungsten-Doped $\mathrm{TiO}_{2}$ vs. Pure $\mathrm{TiO}_{2}$ Photocatalysts: Effects on Photobleaching Kinetics and Mechanism. Journal Physical Chemistry C, 112, 1094-1100.

[9] Tatsuma, T., Saitoh, S., Ngaotrakanwiwat, P., Ohko, Y. and Fujishima, A. (2002) Energy Storage of $\mathrm{TiO}_{2}-\mathrm{WO}_{3}$ Photocatalysis Systems in the Gas Phase. Langmuir, 18, 7777-7779. https://doi.org/10.1021/la026011i

[10] Park, H., Kim, K.Y. and Choi, W. (2002) Photoelectrochemical Approach for Metal Corrosion Prevention Using a Semiconductor Photoanode. Journal Physical Chemistry $B, 106,4775-4781$. https://doi.org/10.1021/jp025519r

[11] Wang, X., Xu, H., Nan, Y., Sun, X., Duan, J., Huang, Y. and Hou, B. (2020) Research Progress of $\mathrm{TiO}_{2}$ Photocathodic Protection to Metals in Marine Environment. Journal of Oceanology and Limnology, 38, 1018-1044.

https://www.researchgate.net/publication/342848348 Research progress of $\mathrm{TiO}_{2}$ photocathodic protection to metals in marine environment https://doi.org/10.1007/s00343-020-0110-x

[12] Xia, Y., Cheng, H., Duo, L., Zhang, D., Chen, X., Shi, S. and Lei, L. (2020) Anticorrosion Reinforcement of Waterborne Polyacrylate Coating with $\mathrm{Nano}^{-\mathrm{TiO}_{2}}$ Loaded Graphene. Journal of Applied Polymer Science, 137, 48733-48740. https://doi.org/10.1002/app.48733

[13] Krishnan, A., Joseph, B., Bhaskar, K.M., Suma, M.S. and Shibli, S.M.A. (2019) Unfolding the Anticorrosive Characteristics of $\mathrm{TiO}_{2}-\mathrm{WO}_{3}$ Mixed Oxide Reinforced Polyaniline Composite Coated Mild Steel in Alkaline Environment. Polymer Composites, 40, 2400-2409. https://doi.org/10.1002/pc.25103

[14] Liang, Y., Guan, Z.C., Wang, H.P. and Du, R.G. (2017) Enhanced Photoelectrochemical Anticorrosion Performance of $\mathrm{WO}_{3} / \mathrm{TiO}_{2}$ Nanotube Composite Films Formed by Anodization and Electrodeposition. Electrochemitry Communications, 77, 120-123. https://www.sciencedirect.com/science/article/pii/S1388248117300693 https://doi.org/10.1016/j.elecom.2017.03.008

[15] Obstarczyk, A., Mazur, M., Kaczmarek, D., Domaradzki, J., Wojcieszak, D., Grobelny, M. and Kalisz, M. (2020) Influence of Post-process Annealing Temperature on Structural, Optical, Mechanical and Corrosion Properties of Mixed $\mathrm{TiO}_{2}-\mathrm{WO}_{3}$ Thin Films. Thin Solid Films, 698, e137856.

https://doi.org/10.1016/j.tsf.2020.137856 
https://www.sciencedirect.com/science/article/abs/pii/S0040609020300717

[16] Ashoka, N.B., Swamy, B.E.K., Jayadevappa, H. and Sharma, S.C. (2020) Simultaneous Electroanalysis of Dopamine, Paracetamol and Folic Acid Using $\mathrm{TiO}_{2}-\mathrm{WO}_{3}$ Nanoparticle Modified Carbon Paste Electrode. Journal of Electroanalytical Chemistry, 859, e113819. https://doi.org/10.1016/j.jelechem.2020.113819 https://www.sciencedirect.com/science/article/abs/pii/S1572665720300023

[17] Abdeen, D.H., Hachach, M.E., Koc, M. and Atieh, M.A. (2019) A Review on the Corrosion Behaviour of Nanocoatings on Metallic Substrates. Materials, 12, 210. https://pubmed.ncbi.nlm.nih.gov/30634551/ https://doi.org/10.3390/ma12020210

[18] Sasirekha, N., Rajesh, B. and Chen, Y.W. (2009) Synthesis of $\mathrm{TiO}_{2}$ Sol in a Neutral Solution Using $\mathrm{TiCl}_{4}$ as a Precursor and $\mathrm{H}_{2} \mathrm{O}_{2}$ as an Oxidizing Agent. Thin Solid Films, 518, 43-48. https://doi.org/10.1016/j.tsf.2009.06.015 https://www.sciencedirect.com/science/article/abs/pii/S0040609009010554

[19] Tryba, B., Piszcz, M. and Morawsk, A.W. (2009) Photocatalytic Activity of $\mathrm{TiO}_{2}-\mathrm{WO}_{3}$ Composites. International Journal of Photoenergy, 2009, Article ID: 297319. https://doi.org/10.1155/2009/297319

https://www.researchgate.net/publication/26844164 Photocatalytic Activity of Ti $\underline{\mathrm{O}_{2}}-\mathrm{WO}_{3}$ Composites 